\title{
Potensi Mahoni (Swietenia macrophylla King) Pada Hutan Rakyat Sistem Kaliwo di Malimada, Sumba Barat Daya
}

\author{
S.Agung Sri Raharjo, Hery Kurniawan, Aziz Umroni, Eko Pujiono, Mellianus Wanaha \\ Balai Penelitian Kehutanan Kupang, NTT; email : herykurniawan2012@gmail.com, agung_sriraharjo@yahoo.co.id
}

\begin{abstract}
ABSTRAK
Hutan rakyat berpotensi menjadi solusi defisit kebutuhan kayu secara lokal maupun nasional. Optimalisasi peran hutan rakyat memerlukan perencanaan yang tepat dan data yang akurat. Penelitian ini bertujuan untuk menentukan potensi dan komposisi kayu penyusun hutan rakyat di Malimada, Kecamatan Wewewa Utara Kabupaten Sumba Barat Daya, Nusa Tenggara Timur. Penelitian menggunakan pendekatan diskriptif kuantitatif dengan metode sampling kuadrat. Sampel berjumlah 10 plot yang diambil secara puposive. Indeks Nilai Peneting (INP) digunakan untuk menggambarkan potency kayu dan komposisi jenis penyusun hutan rakyat. Hasil penelitian menunjukkan bahwa mahoni (Swietenia macrophylla King) mendominasi tegakan dengan nilai INP pada tingkat sapihan, tiang dan pohon berturut-turut adalah 188,28; 211,28 dan 246,04. Struktur tegakan yang ada memiliki karakteristik yang hampir sama dengan hutan alam, hal ini terlihat dari grafik distribusi tingkat pertumbuhan yang berbentuk (J) terbalik (reverse J-shape).
\end{abstract}

Kata kunci : potensi kayu, hutan rakyat, mahoni, analisis vegetasi

\begin{abstract}
Private forests potentially solve the problem of local and national wood deficit. Optimizing the role of private forests, needs proper plannings and accurate data. This study aimed at determining wood potency and composition on private forest of Malimada, North Wewewa sub district, Southwest Sumba District of East Nusa Tenggara. This research used quantitative descriptive approach. Samplings purposive used quadrat methods with 10 plots were established. Important Value Index (IVI) was employed in order to depict wood potency and trees composition of private forest. The research results revealed that standing stock predominantly by mahogany (Swietenia macrophylla King.) with IVI at saplings, poles, and trees level were 188.28; 211.28 and 246.04 respectively. The existing structure stock has similar characteristics to the nature forest, this was indicated by reverse J-shape level of growth distribution curve.
\end{abstract}

Keywords : wood potency, private forest, mahogany, vegetation analysis.

Cara sitasi: Raharjo, S.A.S., Kurniawan, H., Umroni, A., Pujiono, E., Wanaha, M. (2016). Potensi Mahoni (Swietenia macrophylla King) Pada Hutan Rakyat Sistem Kaliwo di Malimada, Sumba Barat Daya. Jurnal Ilmu Lingkungan,14(1),1-10, doi:10.14710/jil.14.1.1-10

\section{PENDAHULUAN}

Indonesia memiliki sekitar 4.000 jenis pohon, yang berpotensi sebagai kayu bangunan. Namun pada saat ini hanya sekitar 400 jenis atau $10 \%$ saja yang memiliki nilai ekonomi dan hanya 260 jenis yang telah digolongkan sebagai kayu perdagangan (Soerianegara dan Lemmens, 2002). Sedangkan kebutuhan kayu nasional mencapai 5758 juta $\mathrm{m}^{3} /$ tahun, disisi lain, kemampuan produksi kayu hutan alam dan hutan tanaman diperkirakan hanya sekitar 45,8 juta $\mathrm{m}^{3}$ /tahun, sehingga terjadi defisit kebutuhan kayu sebesar 11,3 juta $\mathrm{m}^{3} /$ tahun (Kemenlh, 2007., Warisno dan Dahana, 2011). Defisit tersebut dapat ditutupi dari potensi hutan rakyat yang ada, dengan luasan 1.568.415,64 ha hutan rakyat menghasilkan kayu sebesar 39.416.557 $\mathrm{m}^{3}$ (Dephut, 2008). Pada skala regional Nusa Tenggara Timur (NTT) kebutuhan kayu pertukangan sangat tinggi. Secara adat masyarakat di Pulau Timor umumnya memiliki tiga bangunan yaitu Lopo (lumbung), rumah induk, dan dapur. Untuk membangunnya dibutuhkan setidaknya 6,3562 $\mathrm{m}^{3-}$ 7,1266 $\mathrm{m}^{3}$ dalam bentuk kayu log dan papan (Raharjo, et al., 2014). Berdasarkan datadata tersebut hutan rakyat berpotensi menutup defisit kebutuhan kayu secara lokal dan nasional serta mengatasi ketimpangan supply dan demand (Waluyo, et.al, 2010.,Fujiwara et.al., 2011). Hutan rakyat juga telah terbukti berperan dalam rehabilitasi hutan dan lahan, menyediakan stok kayu bulat dan menjadi tabungan bagi keluarga di sekitar hutan (Yumi et al. 2011).

Kepadatan tegakan merupakan bahan untuk mempelajari produktifitas tegakan. Laju pertumbuhan tegakan di hutan tanaman relatif sensitif terhadap variasi kepadatan (Sadono dan 
Umroni, 2012). Kepadatan tegakan di lokasi penelitian perlu dievaluasi kepadatannya karena pola budidaya masyarakat tidak mengikuti pola yang biasa dikembangkan di hutan tanaman.

Penelitian di hutan rakyat sudah banyak dilakukan antara lain berkaitan dengan: karakteristik, komposisi jenis dan pola pengelolaan hutan rakyat di Jawa (Jariyah dan Wahyuningrum, 2008., Widiarti dan Prajadinata, 2008). Sedangkan penelitian di lokasi kaliwo sudah pernah dilakukan oleh Njurumana, et.al (2014) tentang prespektif masyarakat terhadap konservasi keanekaragaman jenis di dalam pola pertanian campur model kaliwo. Njurumana et.al (2013) meneliti tentang konservasi Cendana (Santalum album L.) yang dilaksanakan masyarakat di lahan kaliwo dan Njurumana et.al (2008) yang membandingkan kondisi tanah pada sistem kaliwo dan mamar. Penelitian ini bertujuan untuk menentukan potensi kayu, potensi permudaan, komposisi jenis penyusun hutan rakyat di Malimada, dan kepadatan yang optimal untuk pertumbuhan tegakan mahoni pada sistem pertanian campur model kaliwo.

\section{METODE PENELITIAN}

\subsection{Lokasi dan Waktu Penelitian}

Penelitian dilaksanakan di Desa Malimada, Kecamatan Wewewa Utara, Kabupaten Sumba
Barat Daya (SBD), Provinsi Nusa Tenggara Timur (NTT). Kabupaten SBD merupakan kabupaten pemekaran wilayah Kabupaten Sumba Barat. Secara umum kabupaten ini memiliki karakteristik yang berbeda dengan wilayah lain di Pulau Sumba, Kabupaten SBD memiliki tutupan lahan yang cukup bagus dan curah hujan yang lebih banyak sehingga masyarakatnya memiliki budaya menanam yang cukup kuat. Kegiatan penelitian dilaksanakan pada bulan Juli 2012 .

\subsection{Rancangan Penelitian}

Penelitian ini menggunakan metode deskriptif kuantitatif melalui survey lapangan secara langsung. Sampel berjumlah 10 plot yang ditentukan secara purposive berdasarkan kepentingan yang terkait dengan komposisi jenis dan permudaan alam di Kaliwo dengan metode quadrat plot seperti G ambar 1 (Ardhana, 2012).

Petak ukur ditempatkan di lokasi kaliwo masyarakat yang ditemukan kayu pertukangan (sapihan, tiang dan pohon). Pengambilan plot berdasarkan kepemilikan lahan, satu plot merepresentasikan satu unit kepemilikan lahan. Data yang dikumpulkan adalah jenis tanaman, jumlah tanaman, tinggi tanaman, diameter tanaman dan potensi permudaan.

Penentuan kepadatan tegakan yang optimal untuk hutan rakyat ditentukan dengan indek kepadatan tegakan menurut Reineke (1933).

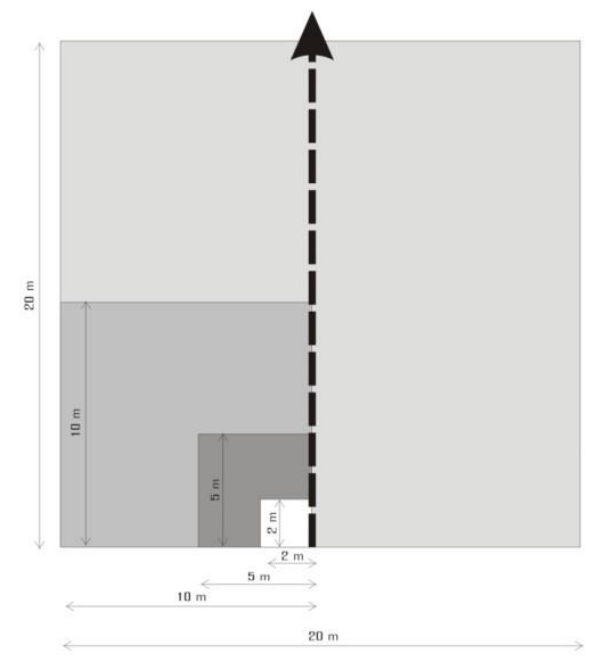

Gambar 1. Bentuk Petak Ukur dalam Pengambilan Data

\subsection{Analisis Data}

Hasil pengukuran dianalisis menggunakan rumus (Ardhana, 2012; Fajri dan Ngatiman, 2012; Atmoko dan Sidiyasa., 2008):

Kerapatan = Jumlah dari individu suatu jenis Luas petak pengamatan $\begin{aligned} & \text { Kerapatan } \\ & \text { Relatif }\end{aligned}=\frac{\text { Kerapatan suatu jenis }}{\text { Kerapatan seluruh jenis }} \times 100 \%$ 
Frekuensi $=\frac{\text { Jumlah petak ditemukan suatu jenis }}{\text { Jumlah seluruh petak pengamatan }}$

$\begin{aligned} & \text { Frekuensi } \\ & \text { Relatif }\end{aligned}=\frac{\text { Frekuensi suatu jenis }}{\text { Frekuensi seluruh jenis }} \times 100 \%$

Dominasi $=\frac{\text { Luas bidang dasar suatu jenis }}{\text { Luas petak pengamatan }}$

$\begin{aligned} & \text { Dominasi } \\ & \text { relatif }\end{aligned}=\frac{\text { Dominasi suatu jenis }}{\text { Dominasi seluruh jenis }}$ X 100\%

Indek Nilai $=$ Kerapatan relatif + Frekuensi relatif Penting + Dominasi relatif

Penentuan Indeks Kepadatan Tegakan dihutan rakyat dihitung dengan persamaan (Reineke, 1933):

$S D I=N\left(\frac{25}{d l b d s}\right)^{-1,605}$
Dimana :

SDI : Stand Density Index

$\mathrm{N} \quad$ : Jumlah pohon dalam satu unit

dlbds : Diameter pada rata-rata luas bidang

dasar

\section{HASIL DAN PEMBAHASAN}

3.1. Hutan Rakyat di Kabupaten SBD

Di Kabupaten Sumba Barat Daya berkembang pengelolaan lahan secara agroforestri, masyarakat setempat menyebutnya Kaliwo. Kaliwo atau pola pertanian lahan kering campuran merupakan bentuk pengelolaan lahan oleh masyarakat secara turun temurun yang terintegrasi dengan lokasi perkampungan penduduk yang di dalamnya dikembangkan berbagai jenis tanaman, baik produktif maupun jenis tanaman yang bernilai sosial budaya (Njurumana et.al. 2008). Sedangkan Vel (1994) menjelaskan bahwa kaliwo merupakan bagian dari rumah yang merupakan satu kesatuan dan tidak dapat diberikan kepada orang lain selain anggota kelompok/keluarga. Gambaran keberadaan kaliwo sebagai bagian dari wilayah perkampungan adat seperti pada Gambar 2.

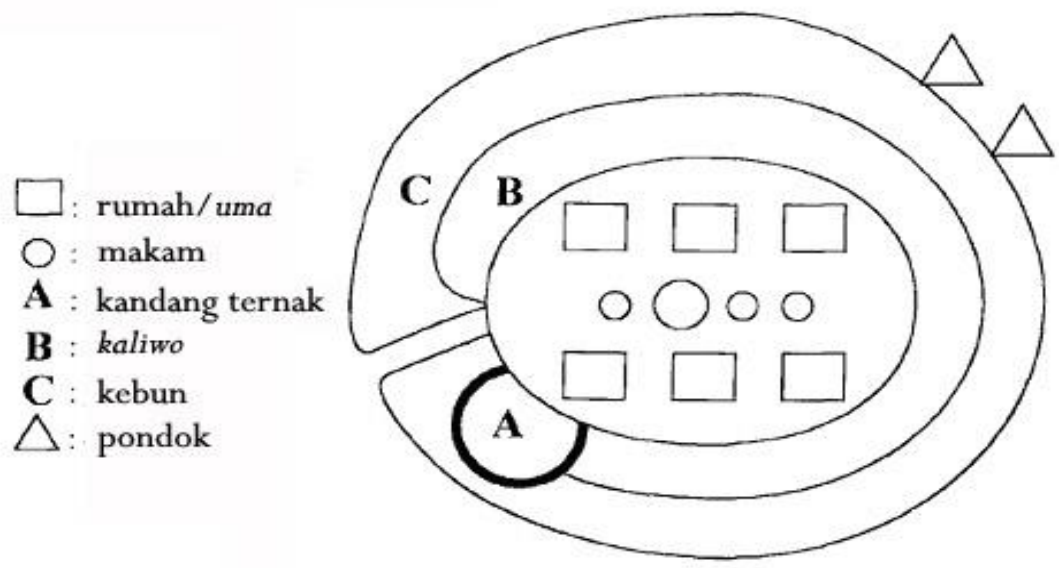

Gambar 2. Landscape perkampungan tradisional di Pulau Sumba (Vel, 1994; 79)

Secara umum jenis tanaman keras yang tumbuh di hutan rakyat di Desa Malimada adalah mahoni (Swietenia macrophylla King.), pulai (Alstonia scholaris), kemiri (Aleurites moluccana), mangga (Mangifera indica), nangka (Arthocarphus heterophyllus), lemme dan elo (nama daerah). Masyarakat memanfaatkan hasil hutan rakyat untuk kebutuhan subsisten dan kebutuhan tambahan. Kayu mahoni digunakan sebagai tabungan untuk memenuhi kebutuhankebutuhan mendesak yang membutuhkan biaya besar seperti membayar biaya sekolah anak, acara adat dan keperluan jaminan saat terjadi gagal panen. Pola pemanfaatan ini sama dengan pemanfaatan hasil hutan rakyat di beberapa daerah di Pulau Jawa antara lain: "tebang butuh" 
atau subsisten, pada lahan milik dan dikelola secara individual (Kusumedi dan Jariyah, 2010; Jariyah dan Wahyuningrum, 2008., Awang, 2004). Sebagian besar produksi kayu mahoni dipasarkan di dalam wilayah Kabupaten Sumba Barat Daya, hanya sebagian kecil yang dijual keluar wilayah Kabupaten Sumba Barat Daya.

Pada lokasi penelitian banyak dikembangkan jenis mahoni yang diintroduksir bersama dengan kegiatan rehabilitasi hutan dan lahan sejak tahun 1970-an. Secara alami, Mahoni tersebar membentang dari selatan meksiko, Amerika Tengah sampai dengan bagian utara Brasil dan di tempat asalnya menjadi jenis kayu tropis yang paling bernilai dan diperdagangkan secara internasional sejak tahun 1750 (Camaracabrales dan Kelty, 2009). Berdasarkan data BPS tahun 2012, jumlah produksi kayu mahoni di NTT pada tahun 2009 sampai dengan tahun 2011 meningkat dari $699 \mathrm{~m}^{3}$ /tahun menjadi $2.054 \mathrm{~m}^{3} /$ tahun. Kayu mahoni ini sebagian besar berasal dari dari hutan rakyat, salah satunya dari kawasan kaliwo yang ada di Kabupaten SBD.

\subsection{Komposisi Penyusun Tegakan}

Sebaran tingkat pertumbuhan tegakan mahoni pada plot pengamatan terbanyak adalah semai, kemudian diikuti oleh jumlah sapihan, tiang dan pohon, seperti dapat dilihat pada Gambar 3. Secara umum hutan rakyat model kaliwo yang terdapat dilokasi penelitian tidak dilakukan pemeliharaan seperti: penjarangan, pengaturan jarak tanam dan pengkayaan jenis. Sehingga kondisi distribusi kelas pertumbuhan dari semai sampai tingkatan pohon di dalam tegakan mahoni relatif identik dengan kondisi hutan alam pada kondisi uneven age forest. Menurut Davis dan Johnson (1986) kondisi uneven age seperti pada hutan alam ditandai dengan grafik tingkat pertumbuhan dari pohon sampai semai yang membentuk kurva "J" terbalik (reverse "J" shape curve) dengan distribusi paling banyak adalah semai dan paling sedikit adalah pada tingkatan pohon.

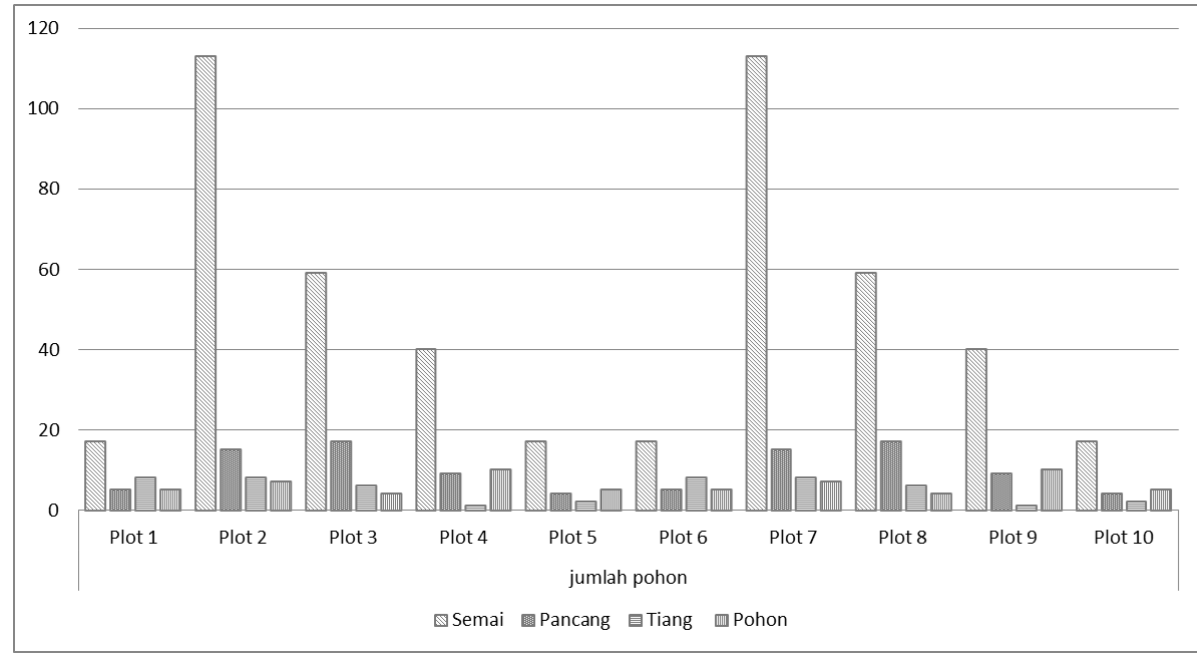

Gambar 3. Graphic distribution of seedling, sapling, poles and trees

Distribusi semai yang banyak menandakan potensi permudaan yang baik. Namun hal ini tidak mengikuti pola yang lazim terjadi di hutan tanaman seperti pengusahaan yang intensif. Sebaran kelas pertumbuhan pada hutan tanaman atau pada kondisi even age akan mengikuti pola distribusi normal atau bellshaped distribution curve (Davis dan Johnson, 1986). Namun pola distribusi kelas pertumbuhan yang terdapat di dalam kaliwo tidak mengikuti pola tersebutHal ini antara lain dikarenakan: (1). Masyarakat mengandalkan permudaan alami untuk meregenerasi tegakan yang ada (2). masyarakat hanya mengambil pohon-pohon yang sudah besar yang biasanya ditebang sesuai dengan kebutuhan (subsisten) dan (3) pengaruh pemilihan jenis (mahoni) yang adaptif dan mudah menyebar (dispersal). Sebaran biji Mahoni menjangkau area seluas 0,37-0,47 $\mathrm{Ha}$, dengan jangkauan 30-50 m dari pohon induk dan rata-rata menghasilkan 133 kapsul biji/pohon yang berisi 45 biji bersayap per kapsul biji yang 75 persennya merupakan biji yang viable (Cabrales dan Kelty, 2009). Hal ini menjadi salah satu penyebab jenis mahoni mampu mendominasi seperti ditunjukkan pada Lampiran 1.

Pada Tabel 1 terlihat bahwa pada tingkatan pohon, rata-rata diameternya $30,8 \mathrm{~cm}$ dengan rata-rata tingginya $17,26 \mathrm{~m}$. Kondisi ini cukup mengkhawatirkan mengingat batas diameter pohon yang boleh ditebang menurutperaturan daerah (perda) yang berlaku adalah $\geq 30 \mathrm{~cm}$. Batas diameter ini jauh lebih 
Raharjo, S.A.S., Kurniawan, H., Umroni, A., Pujiono, E., Wanaha, M. (2016). Potensi Mahoni (Swietenia macrophylla King) Pada Hutan Rakyat Sistem Kaliwo di Malimada, Sumba Barat Daya. Jurnal Ilmu Lingkungan,14(1),1-10, doi:10.14710/jil.14.1.1-10

kecil jika dibandingkan dengan batas diameter untuk komersial trading yang berlaku di Brasil yaitu $\geq 60 \mathrm{~cm}$ (Grogan et al., 2014). Selisih ratarata diameter pohon di tegakan yang ada (existing stock) dengan batas diameter yang boleh ditebang menunjukkan bahwa potensi keberlangsungan atau ketersediaan stok (sustainability) rentan untuk dieksploitasi secara berlebihan.

Tabel 1. Rata-rata Jenis Mahoni di Seluruh PU dan Potensi Tingkat Pertumbuhan

\begin{tabular}{|c|c|c|c|c|}
\hline $\begin{array}{c}\text { Tingkat } \\
\text { Level }\end{array}$ & \multicolumn{3}{|c|}{$\begin{array}{c}\text { Rerata PU } \\
\text { Plot average }\end{array}$} & $\begin{array}{l}\text { N/ha } \\
N / h a\end{array}$ \\
\hline Semai & - & - & 49,9 & 124.750 \\
\hline Tiang & 13,91 & 11,56 & 3,3 & 330 \\
\hline Pohon & 30,83 & 17,26 & 6 & 150 \\
\hline
\end{tabular}

Potensi permudaan mahoni yang tumbuh di Desa Malimada melimpah dan potensial untuk dapat melakukan regenerasi dengan baik. Masyarakat di Malimada meyakini bahwa permudaan alami mampu tumbuh lebih baik dari permudaan buatan sehingga hampir seluruh areal kondisi tegakannya sangat rapat dengan potensi permudaan yang sangat tinggi. Hal ini berbeda dengan hasil penelitian Shono dan Snook (2006) di Balize yang menyatakan adanya keterbatasan permudaan mahoni di hutan bekas tebangan di Balize (Amerika Tengah) dan sekitarnya. Permudaan mahoni memerlukan kondisi antara lain: cahaya yang cukup, kompetisi tanaman bawah yang rendah dan area yang terbuka antara 500-5.000 $\mathrm{m}^{2}$ (Shono dan Snook, 2006., Camara-Cabrales dan Kelty, 2009). Kondisi lahan di lokasi penelitian menunjukkan bahwa diluar lokasi dengan vegetasi yang rapat merupakan padang savana, hal ini memberikan ruang tumbuh yang optimal untuk anakan mahoni tersebar.

Sementara apabila dibuat suatu perbandingan secara rata rata untuk setiap plot maka perbandingan jumlah pohon per hektar untuk tingkat pertumbuhan semai : sapihan : tiang : pohon adalah 8,3 : 1,9:0,5: 1 secara berturut-turut. Kondisi ini relatif proporsional kecuali pada tingkatan Tiang dimana kelimpahannya lebih sedikit dari tingkatan pohon. Gap yang terjadi pada tingkatan Tiang dapat terjadi karena kanopi belum terbuka akibat okupasi mahoni pada tingkatan pohon (oportunity gap) sehingga menekan pertumbuhan tanaman dibawahnya. Mengingat mahoni merupakan jenis yang membutuhkan sinar (light-damanding), jenis yang pertumbuhannya dapat meningkat ketika gap kanopinya terbuka dan mampu bertahan terhadap cekaman cahaya (Camara-Cabrales dan Kelty, 2009., Poorter, 1999).

\subsection{Analisis Vegetasi}

Indeks Nilai Penting (INP) merupakan salah satu pisau analisis yang membantu dalam menjelaskan nilai penting suatu jenis secara relatif terhadap jenis lainnya dan kawasannya. Nilai penting suatu jenis dapat menggambarkan tingkat dominasi atau penguasaan, sebaran dan kerapatan suatu jenis disuatu kawasan (Hany dan Suryanto, 2014). Secara keseluruhan di wilayah Desa Malimada, mahoni memiliki INP yang tinggi pada setiap tingkat pertumbuhannya. Secara detail hasil analisis vegetasi dapat dilihat pada Lampiran 1.

Urutan jenis dengan nilai INP tiga tertinggi pada kelas pohon adalah Mahoni (188), Kemiri (40) dan Kelapa (25). Kerapatan pohon pada tingkatan ini 215 individu ha-1 dengan luas bidang dasar (lbds) secara keseluruhan sebesar $17,9 \mathrm{~m}^{2} \mathrm{ha}^{-1}$. Dari lbds tersebut, mahoni memberikan kontribusi sebesar $13,47 \mathrm{~m}^{2} \mathrm{ha}^{-1}$ atau 75 persennya. Mahoni menjadi jenis yang dominan dilihat dari angka lbdsnya, hal dapat terjadi karena mahoni mudah tersebar dan termasuk jenis fast growing (Lamb, 1966). Mahoni selain mendominasi juga mempunyai kerapatan yang tinggi, dari total kerapatan pohon di lokasi penelitian (215 ind $\left.\mathrm{ha}^{-1}\right)$ mahoni berjumlah(150 ind ha-1) dengan sebaran yang merata. Asal usul kayu, potensi kayu dan sebaran mahoni yang besar di hutan rakyat di Kabupaten Sumba Barat Daya berpotensi untuk dikelola sebagai penyuplai industri kayu dengan sertifikasi verifikasi legalitas kayu (SVLK), sehingga meningkatkan nilai jualnya, mengingat mahoni merupakan komoditas kayu 
yang paling bernilai dari hutan tropis Amerika (Shono dan Snook, 2006).

Potensi permudaan mahoni pada tingkat tiang, pancang dan semai antara kriteria tinggi sampai sangat tinggi, dimana INPnya berturutturut adalah 211,3 (sangat tinggi); 246 (sangat tinggi) dan 168 (tinggi). Sementara itu, komposisi penyusun tegakan dilihat dari INP pada tingkatan tiang setelah mahoni adalah Nangka (24,7) dan Pinang $(15,9)$. Pada tingkatan pancangsetelah mahoni adalah Mangga dan Pulai dengan INP berturut-turut sebesar 17,6 dan 15,4 dan pada tingkatan semai setelah mahoni adalah Kopi (INP=15,8) dan Lamtoro (INP=8,5).

Secara umum komposisi penyusun tegakan di hutan rakyat Malimada didominasi oleh mahoni pada setiap tingkatan pertumbuhan apabila dilihat dari okupasi atau luas bidang dasarnya, sebaran dan kerapatan ha $^{-1}$. Berdasarkan tingkat dominasinya, kesenjangan (gap) mahoni terhadap jenis lainnya di lokasi penelitian mencapai satu per sepuluh. Hal dapat terjadi karena: (1). Tapak dilokasi penelitian mengindikasikan sebagai preferensi tumbuh mahoni. Mahoni dihabitat alaminya mempunyai preferensi tumbuh subur di tanah yang berwarna hitam (lebih kaya bahan organik, kalsium dan Phosfor), pada lahan yang relatif datar (Negreros-castillo dan Mize, 2013). Sementara sumba barat relatif mempunyai curah hujan yang cukup, tanah yang sesuai dan awalnya merupakan savana terbuka (pengamatan obyektif). (2). Jenis yang baru di introduksir dan memiliki nilai ekonomi yang tinggi, sehingga dengan cepat menjadi preferensi masyarakat (3). Mahoni termasuk jenis tanaman yang menghasilkan senyawa allelopathy.

Menurut Cummings et.al (2012) yang melakukan penelitian pada lahan agroforestry mahoni, hambatan pertumbuhan tanaman bawah dimana tidak ada kompetisi cahaya, air dan nutrisi bisa jadi disebabkan oleh adanya allelopathy yang menekan pertumbuhan tanaman bawah.

\subsection{Kepadatan Tegakan}

Indeks kepadatan tegakan atau stand density index (SDI) dideskripsikan sebagai kepadatan tegakan dengan diameter pada ratarata luas bidang dasar dan jumlah pohon per hektar yang berhubungan secara alometri (Sadono dan Umroni, 2012). Meskipun SDI pada saat awalnya dikembangkan untuk tegakan murni dan seumur, persamaan SDI ini dengan beberapa penyesuaian (SDI untuk tiap kelas diameter) pernah digunakan untuk tegakan monokultur, multikultur dan tidak seumur (Woodall, et.al, 2005). Premis utama dari SDI yang dikembangkan oleh Reineke adalah apabila rata-rata ukuran (size) atau diameter pohon dari suatu area meningkat pada saat yang sama jumlah pohon per unit area akan menururun (Woodall et.al, 2003).

Kerapatan mahoni ha-1 pada $\mathrm{dbh}>10$ cm pada hutan rakyat di Desa Malimada (480 ind $\mathrm{ha}^{-1}$ ) diatas jumlah pohon mahoni pada hutan rakyat di Kabupaten Sidrap 400 ind ha ${ }^{-1}$ (Rizal et al., 2012). Kerapatan pohon ha-1 secara total di hutan rakyat Malimada pada dbh>10 $\mathrm{cm}$ adalah 635 pohon ha-1 sementara pada hutan rakyat pola kebun campuran di Sukabumi 613 pohon ha ${ }^{-1}$, di hutan alam di Kalimantan Tengah 621 pohon ha-1(Widiarti dan Prajadinata, 2008) dan dihabitat alami mahoni di Meksiko kerapatannya 658 pohon ha $^{-1}$ (Camara-cabrales dan Kelty, 2009).

Kepadatan tegakan akan mencapai maksimalnya pada kondisi kepadatan maksimum (fullstock). Kondisi kepadatan maksimum dapat ditandai dengan beberapa ciri antara lain: proses permudaan yang sedikit, terdapat pohon yang tertekan dalam jumlah yang signifikan dan gap tajuk yang relatif kecil (Woodall, 2003). Apabila menggunakan pendekatan kepadatan sebagaimana di habitat alaminya sebesar 658 dan diameter acuan 30 $\mathrm{cm}$ sesuai diameter minimal perdagangan setempat diperoleh $\mathrm{SDI}_{\max }$ sebesar 880 . Sehingga secara umum nilai SDI di lokasi penelitian pada setiap level pertumbuhan berada di bawah SDI maksimal seperti dapat dilihat pada Lampiran 2. Hal ini mengindikasikan pada lokasi penelitian, tegakannya belum mencapai maksimum (fullstock). Kondisi ini sesuai dengan ciri-ciri tegakan pada kondisi understock antara lain: adanya permudaan yang baik (vigorous regeneration), gap kanopi yang cukup (sufficient canopy gap) dan kurangnya kompetisi dan tekanan tanaman bawah (Woodall, 2003).

Hal ini perlu menjadi salah satu pertimbangan bahwa jumlah pohon dalam satu hektar masih bisa terus di tingkatkan sehingga produktifitas hutan rakyat lebih optimal. Karakteristik mahoni yang menekan pertumbuhan jenis lain di bawahnya, memaksa masyarakat untuk cermat mengatur ruang tumbuh hutan rakyatnya agar tanaman pertanian mendapatkan ruang untuk tumbuh. Salah satu upaya yang dapat dilakukan adalah dengan membuka lahan baru untuk lahan pertanian yang terbebas dari naungan mahoni secara langsung. Sementara itu lahan yang telah ditumbuhi mohoni dipelihara secara monokultur khusus untuk mahoni. 


\section{KESIMPULAN}

Berdasarkan hasil dan pembahasan di atas maka dapat disimpulkan bahwa Komposisi jenis di hutan rakyat Desa Malimada didominasi oleh mahoni (Swietenia macrophylla King.) dan cenderung monokultur. Hal ini ditunjukkan dengan nilai INP yang relatif tinggi pada tingkat sapihan, tiang dan pohon untuk mahoni berturut-turut adalah sebesar 246,04; 211,28; 188,28. Jenis mahoni yang mendominasi pada sisi lain menekan spesies asli yang bernilai budaya seperti: mayela (Artocarpus glaucus), injuwatu (Pleigynium timoriensis) dan kadimbil (Instia sp), sehingga diperlukan upaya konservasi jenis-jenis lokal potensial. Hutan rakyat mahoni yang ada memiliki karakteristik pertumbuhan yang hampir sama dengan hutan alam yang ditandai dengan bentuk kurva reverse J-shape pada distribusi level pertumbuhannya, hal ini mengindikasikan peluang keberlanjutan yang tinggi. Secara umum kepadatan tegakan dihutan rakyat Malimada berada dibawah kepadatan optimalnya, sehingga penambahan tanaman masih mungkin dilakukan.

\section{SARAN}

Pemisahan lokasi pertanaman mahoni dengan tanaman lain seperti kopi dan tanaman pertanian perlu dilakukan. Hal ini mengingat persebaran mahoni secara alami di Desa Malimada sangat tinggi, sehingga dikhawatirkan mengganggu produksi tanaman perkebunan maupun tanaman pertanian yang ada. Hal ini dapat dilakukan dengan mengurangi sebaran mahoni yang berada di lokasi tanaman perkebunan atau tanaman pertanian.

\section{UCAPAN TERIMA KASIH}

Peneliti menyampaikan ucapan terima kasih kepada para pihak yang telah membantu penelitian ini terutama kepada Bapak Paulus Solo (KRPH Wewewa Utara) atas dukungan dan kerjasamanya dalam pelaksanaan penelitian. Ucapan terima kasih juga kami sampaikan kepada Bapak/Ibu yang telah membantu penyusunan dan penerbitan naskah ini.

\section{DAFTAR PUSTAKA}

Ardhana, I.P.G., 2012. Ekologi Tumbuhan. Udayana University Press. Denpasar. Indonesia.

Atmoko, T dan Sidiyasa, K., 2008.Karakteristik Vegetasi Habitat Bekantan ( Nasalis larvatus Wurmb) Di Delta Mahakam, Kalimantan Timur.Jurnal Penelitian Hutan dan Konservasi Alam. Vol. V No. 4 : 307-316
Awang, S. A., 2004. Dekonstruksi Sosial Forestry: Reposisi Masyarakat dan Keadilan Lingkungan. Bigraf, Yogyakarta. Hal. 10.

Camara-Cabrales, L., Kelty, M.J., 2009. Seed Dispersal of Big Leaf Mahogany (Swietenia macrophylla) and its Role in Natural Forest Management in Yucatan Peninsula, Mexico. Journal of Tropical Forest Science. 21(3): 235-245.

Cummings, J.A., Parker, I.M., and Gilbert, G.S., 2012. Allelopathy: a Tool for Weed Management in Forest Restoration. Plant Ecology 2012. 213; 1975-1989. DOI 10.1007/s11258-012-0154-x

Departemen Kehutanan. 2008. Statistik Kehutanan Indonesia 2008. Sub Direktorat Statistik dan Jaringan Komunikasi Data Kehutanan. Jakarta.

Davis, L. S., Johnson, K.N., 1986. Forest Management. McGraw-Hill Book Company. New York.

Fajri, M. dan Ngatiman, 2012.Analisis Vegetasi Dan Assosiasi Jenis Pada HabitatParashoreamalaanonan MERR. Info Teknis Dipterokarpa Vol. 5 No. 1, September $2012: 13-23$.

Fujiwara, T., Awang, S.A., Widayanti, W.T., Septiana, R.M., Bariatul, H., Rahmat, M., Suyanto, A., and Sato, N., 2011. Overcoming Vulnerability of Privately Owned Small-Scale Forest Through Collective Management Unit Establishment: A Case Study of Gunung Kidul District, Yogyakarta In Indonesia. International Journal of Social Forestry (IJSF), 2011, 4 (2):113-138.

Grogan, J., Landis, R.M., Free, C.M., Schulze, M.D., Lentini, M., and Ashton, M.S., 2014. Big-leaf mahogany Swieteniamacrophyllapopulation dynamics and implications for sustainable management. Journal of Applied Ecology. Doi:10.1111/1365-2664.12210

Hany, A., Suryanto, P., 2014. Dinamika Agroforestry Tegalan di Perbukitan Menoreh. Jurnal Penelitian Kehutanan Wallacea. Vol. 3, No.2: 119-128.

Jariyah, N.A. dan Wahyuningrum, N., Karakteristik Hutan rakyat di Jawa. Jurnal Penelitian Sosial dan Ekonomi Kehutanan. Vol 5. No 1. Maret 2008. Hal 43-56.

Kusumedi, P. dan Jariyah, N.A., 2010. Analisis Finansial Pengelolaan Agroforestri dengan Pola Sengon Kapulaga di Desa Tirip, Kecamatan Wadaslintang, Kabupaten Wonosobo. Jurnal Penelitian Sosial dan Ekonomi Kehutanan Vol. 7 No. 2 Juni 2010, Hal. 93 100 .

Lamb, F.B., 1966. Mahogany of Tropical America : Its Ecology and Management. University of Michigan Press. Ann Arbor, MI.

Negreros-castello, P., Mize, C.W., 2013. Soil-site Preferences for Mahogany (Swietenia macrophylla King.)in Yucatan Peninsula. New Forest Vol. 44: 85-99.

Njurumana, G. N., Hidayatullah, M. dan Butarbutar, T., 2008. Kondisi Tanah Pada Sistem Kaliwo Dan Mamar Di Timor Dan Sumba. Info Hutan Vol. V No. 1 : 45-51

Njurumana, G. N., D. Marsono., Irham., R. Sadono., 2014. Konservasi Keanekaragaman Hayati Tanaman Pada Sistem Kaliwu di Pulau Sumba. Jurnal Manusia dan Lingkungan Vol. 21 No. 1. Maret 2014. Hal 75-82. 2013. Konservasi Cendana (Santalum album L.) Berbasis Masyarakat Pada Sistem Kaliwu di Pulau Sumba. Jurnal Ilmu Lingkungan Vol. 11 Issue 2: 51-61.

Poorter, L., 1999. Growth Responses of 15 Rain-forest Tree Species to a Light Gradient: The Relative Importance of Morphological and Physiological Traits.Functional Ecology Vol. 13: 396-410

Raharjo, S.A.S., Yuniati, D., Prasetyo, B.D., Umroni, A., dan Lalus, M., 2014. Analisis Kebutuhan Kayu masyarakat di Desa Oenain Kecamatan Insana Fafinesu kabupaten Timor tengah Utara ( Wood Needs Anlysis of the People in Oenain village, Insana Fafinesu Sub District, Timor Tengah Utara District). Jurnal Flobamora Vol 09 No 01 Maret 2014. Hal: 1-12 
Reineke, L. H., 1933.Perfecting a Stand Density Index for Even Age Forest. Journal of Agriculture Research46:627-638.

Rizal, H.B.A., Nurhaedah dan Hapsari, E..2012. Kajian Strategi Optimalisasi Pemanfaatan Lahan Hutan Rakyat Di Provinsi Sulawesi Selatan.Jurnal Penelitian Sosial dan Ekonomi Kehutanan Vol. 9 No. 4 Desember 2012, Hal. 216 - 228.

Sadono, R.,Umroni, D., 2012. Penentuan Indeks Kepadatan Sengon di Hutan Rakyat (Kecamatan Kranggan dan Pringsurat Kabupaten Temanggung). Jurnal Ilmu Kehutanan Vol. VI (1): 53-60

Soerianegara, I. dan RHMJ. Lemmens (eds.). 2002. Sumber Daya Nabati Asia Tenggara 5(1): Pohon penghasil kayu perdagangan yang utama. PROSEA - Balai Pustaka. Jakarta. ISBN 979-666-308-2.Hal. 7

Shono, K and Snook, L.K., 2006. Growth of Big-Leaf Mahogany (Swietenia Macrophylla) in Natural Forests in Belize. Journal of Tropical Forest Science 18(1): 66--73

Vel, J.. 1994. The Uma-economy: Indigenous Economics and Development Work in Lowanda Sumba (Eastern Indonesia). Thesis.WageningenUniversity.Holand.

Waluyo, E.A., Ulya, N.A. dan Martin, E., 2010. Perencanaan Sosial dalam Rangka Pengembangan Hutan Rakyat di Sumatera Selatan (Social Planning on Community
Forest Development in South Sumatra).Jurnal Penelitian Hutan dan Konservasi Alam. Vol VII. No 3. Hal 271-280.

Warisno dan K.Dahana..2011. Peluang Investasi Jabon Tanaman Kayu Masa Depan. PT.Gramedia Pustaka Utama. Jakarta

Widiarti, A., Prajadinata, S., 2008. Karakteristik Hutan Rakyat Pola Kebun Campuran. Jurnal Penelitian Hutan dan Konservasi Alam Vol. 5 (2): 145-156

Woodall, C.W., Miles, P.D., Vissage, J.S., 2005. Determining Stand Density Index in Mixed Species Stands for Strategic-scale Stocking Assessments. Forest Ecology and Management Vol. (216):367-377

Woodall, C.W., Fiedler, C. E., Milner, K. S., 2003. Stand Density Index in Uneven-age Ponderosa Pine Stands. Canadian Journal Of Forest Research Vol. (33): 96100.

Yumi, Sumardjo, Gani, D.S., Sugihen, B.S., 2011. Model Pengembangan Pembelajaran Petani Dalam Pengelolaan Hutan Rakyat Lestari: Kasus di Kabupaten Gunung Kidul, Provinsi Daerah Istimewa Yogyakarta dan Kabupaten Wonogiri, Provinsi Jawa Tengah. JurnalPenelitian Sosial dan Ekonomi Kehutanan Vol. 8 No. 3 September 2011, Hal. 196 210. 
Raharjo, S.A.S., Kurniawan, H., Umroni, A., Pujiono, E., Wanaha, M. (2016). Potensi Mahoni (Swietenia macrophylla King) Pada Hutan Rakyat Sistem Kaliwo di Malimada, Sumba Barat Daya. Jurnal Ilmu Lingkungan,14(1),1-10, doi:10.14710/jil.14.1.1-10

Lampiran 1. Komposisi jenis di hutan rakyat dengan pola kebun campuran model Kaliwo di Malimada, Sumba Barat Daya.

Tingkat pertumbuhantingkat pohon (Trees level of growth)

\begin{tabular}{|c|c|c|c|c|c|c|c|c|c|}
\hline No & $\begin{array}{c}\text { Jenis } \\
\text { (Species) }\end{array}$ & $\begin{array}{c}\text { Nama Botani (Botanical } \\
\text { name) }\end{array}$ & $\mathrm{F}$ & $\begin{array}{c}\mathrm{FR} \\
(R F) \\
(\%)\end{array}$ & D & $\begin{array}{c}\text { DR } \\
(R D) \\
(\%)\end{array}$ & $\begin{array}{c}\mathrm{K} \\
(D)\end{array}$ & $\begin{array}{l}\mathrm{KR} \\
(R D) \\
(\%)\end{array}$ & $\begin{array}{l}\text { INP } \\
(I V I)\end{array}$ \\
\hline 1 & Mahoni & $\begin{array}{l}\text { Swietenia macophylla } \\
\text { King. }\end{array}$ & 1,00 & 43,48 & 13,47 & 75,04 & 150 & 69,77 & 188,28 \\
\hline 2 & Kemiri & $\begin{array}{l}\text { Aleurites moluccana L } \\
\text { Wild.,1805 }\end{array}$ & 0,40 & 17,39 & 2,07 & 11,54 & 25 & 11,63 & 40,56 \\
\hline 3 & kelapa & Cocos nucifera L. & 0,20 & 8,70 & 1,36 & 7,55 & 20 & 9,30 & 25,55 \\
\hline 4 & Nangka & $\begin{array}{l}\text { Arthocarpus } \\
\text { heterophyllus Lamk. }\end{array}$ & 0,30 & 13,04 & 0,60 & 3,32 & 10 & 4,65 & 21,01 \\
\hline 5 & Lamtoro & $\begin{array}{l}\text { Leucaena } \\
\text { leucocephalaLamk. }\end{array}$ & 0,10 & 4,35 & 0,14 & 0,76 & 2,5 & 1,16 & 6,27 \\
\hline 6 & Mindi & Melia azedarach L.) & 0,10 & 4,35 & 0,13 & 0,75 & 2,5 & 1,16 & 6,26 \\
\hline 7 & Elo & - & 0,10 & 4,35 & 0,11 & 0,61 & 2,5 & 1,16 & 6,12 \\
\hline \multirow[t]{2}{*}{8} & Dopa & - & 0,10 & 4,35 & 0,08 & 0,44 & 2,5 & 1,16 & 5,95 \\
\hline & & Total & 2,3 & 100 & 17,95 & 100 & 215 & 100 & 300 \\
\hline
\end{tabular}

\begin{tabular}{|c|c|c|c|c|c|c|c|c|c|}
\hline No & Jenis (Species) & $\begin{array}{c}\text { Nama Botani (Botanical } \\
\text { name) }\end{array}$ & $\mathrm{F}$ & $\begin{array}{c}\text { FR } \\
(R F) \\
(\%)\end{array}$ & $\mathrm{D}$ & $\begin{array}{c}\mathrm{DR} \\
(R D) \\
(\%)\end{array}$ & $\begin{array}{c}\mathrm{K} \\
(D)\end{array}$ & $\begin{array}{c}\mathrm{KR} \\
(R D) \\
(\%)\end{array}$ & $\begin{array}{l}\text { INP } \\
(I V I)\end{array}$ \\
\hline 1 & Mahoni & $\begin{array}{l}\text { Swietenia macophylla } \\
\text { King. }\end{array}$ & 0,90 & 56,25 & 5,05 & 76,46 & 330 & 78,57 & 211,28 \\
\hline 2 & Nangka & $\begin{array}{l}\text { Arthocarpus } \\
\text { heterophyllus Lamk. }\end{array}$ & 0,20 & 12,50 & 0,49 & 7,47 & 20 & 4,76 & 24,73 \\
\hline 3 & Pinang & Areca catecu L. & 0,10 & 6,25 & 0,32 & 4,89 & 20 & 4,76 & 15,90 \\
\hline 4 & Dopa & - & 0,10 & 6,25 & 0,26 & 3,94 & 20 & 4,76 & 14,95 \\
\hline 5 & Kemiri & $\begin{array}{l}\text { Aleurites moluccana L } \\
\text { (Wild.,1805) }\end{array}$ & 0,10 & 6,25 & 0,24 & 3,64 & 10 & 2,38 & 12,27 \\
\hline 6 & Lamme & - & 0,10 & 6,25 & 0,14 & 2,12 & 10 & 2,38 & 10,76 \\
\hline \multirow[t]{2}{*}{7} & Rambutan & $\begin{array}{l}\text { Nephelium lappaceum } \\
\text { L. }\end{array}$ & 0,10 & 6,25 & 0,10 & 1,48 & 10 & 2,38 & 10,11 \\
\hline & & & 1,60 & 100 & 6,61 & 100 & 420 & 100 & 300 \\
\hline
\end{tabular}

\begin{tabular}{|c|c|c|c|c|c|c|c|c|c|}
\hline No & Jenis (Species) & $\begin{array}{c}\text { Nama Botani (Botanical } \\
\text { name) }\end{array}$ & $\mathrm{F}$ & $\begin{array}{c}\mathrm{FR} \\
(R F) \\
(\%)\end{array}$ & $\mathrm{D}$ & $\begin{array}{c}\mathrm{DR} \\
(R D) \\
(\%)\end{array}$ & $\begin{array}{c}\mathrm{K} \\
(D)\end{array}$ & $\begin{array}{c}\mathrm{KR} \\
(R D) \\
(\%)\end{array}$ & $\begin{array}{l}\text { INP } \\
(I V I)\end{array}$ \\
\hline 1 & Mahoni & $\begin{array}{l}\text { Swietenia macophylla } \\
\text { King. }\end{array}$ & 1,00 & 71,43 & 5,71 & 84,14 & 4560 & 90,48 & 246,04 \\
\hline 2 & Mangga Hutan & Mangifera sp L. & 0,10 & 7,14 & 0,50 & 7,31 & 160 & 3,17 & 17,63 \\
\hline 3 & Pulai & $\begin{array}{l}\text { Alstonia scholaris L. } \\
\text { R.Br }\end{array}$ & 0,10 & 7,14 & 0,45 & 6,65 & 80 & 1,59 & 15,38 \\
\hline 4 & Kopi & Coffea arabica & 0,10 & 7,14 & 0,06 & 0,87 & 160 & 3,17 & 11,18 \\
\hline \multirow[t]{2}{*}{5} & Lamtoro & $\begin{array}{l}\text { Leucaena leucocephala } \\
\text { Lamk. }\end{array}$ & 0,10 & 7,14 & 0,07 & 1,04 & 80 & 1,59 & 9,77 \\
\hline & & & 1,4 & 100 & 6,79 & 100 & 5040 & 100 & 300 \\
\hline
\end{tabular}

Kelas pertumbuhan tingkat Semai (Seedling level of growth)

\begin{tabular}{cllccccc}
\hline No & Jenis (Species) & $\begin{array}{l}\text { Nama Botani (Botanical } \\
\text { name })\end{array}$ & F & $\begin{array}{c}\text { FR }(R F) \\
(\%)\end{array}$ & K $(D)$ & $\begin{array}{c}\text { KR (RD) } \\
(\%)\end{array}$ & INP (IVI) \\
\hline Mahoni & $\begin{array}{l}\text { Swietenia macophylla } \\
\text { King. } \\
\text { Kopi }\end{array}$ & 1 & 71,43 & 124750 & 96,89 & 168,32 \\
Coffea arabica & 0,2 & 14,29 & 2000 & 1,55 & 15,84 \\
Lamtoro & $\begin{array}{l}\text { Leucaena leucocephala } \\
\text { (Lamk) }\end{array}$ & 0,1 & 7,14 & 1750 & 1,36 & 8,50 \\
Sirsak & Annona muricata L. & 0,1 & 7,14 & 250 & 0,19 & 7,34 \\
\hline
\end{tabular}

Keterangan (Remark):

$\mathrm{F}=$ Frekuensi (frequency), FR $(R F)=$ Frekuensi relatif (relative frequency), $\mathrm{D}=$ Dominasi (domination), $\mathrm{DR}(\mathrm{RD})=$ Dominasi relatif (relative domination), $\mathrm{K}(\mathrm{D})=$ Kerapatan $($ Density), $\mathrm{KR}(R D)=$ Kerapatan relatif $($ Relatif density), $\mathrm{INP}(I V I)=$ Indeks Nilai Penting (importance value index) 
Lampiran 2. Indeks kepadatan tegakan

(Appendix 2. Stand density index).

\begin{tabular}{|c|c|c|c|c|c|c|c|c|}
\hline \multicolumn{2}{|c|}{$\begin{array}{c}\text { Plot (pada setiap } \\
\text { level } \\
\text { pertumbuhan) }\end{array}$} & lbds $\left(m^{2}\right)$ & $\begin{array}{l}\text { Lbds/Ha } \\
\left(\mathrm{m}^{2} / \mathrm{Ha}\right)\end{array}$ & \multirow[t]{2}{*}{ lbds $\left(\mathrm{cm}^{2}\right)$} & \multirow[t]{2}{*}{$D_{l b d s}(\mathrm{~cm})$} & $\mathrm{N}$ & $\mathrm{N} / \mathrm{Ha}$ & SDI \\
\hline & $\left.1^{*}\right)$ & 0,714 & 17,86 & & & 5 & 125 & 294,7 \\
\hline & $* *)$ & 0,120 & 11,96 & 149,47 & 13,80 & 8 & 800 & 308,2 \\
\hline & $* * *)$ & 0,010 & 4,08 & 81,59 & 10,20 & 5 & 500 & 118,5 \\
\hline & $2 *)$ & 0,910 & 22,74 & 1299,32 & 40,68 & 7 & 175 & 382,4 \\
\hline & $* *)$ & 0,119 & 11,90 & 148,73 & 13,76 & 8 & 800 & 307,0 \\
\hline & $* * *)$ & 0,026 & 10,20 & 68,00 & 9,31 & 15 & 1500 & 307,2 \\
\hline & $3 *)$ & 0,773 & 19,32 & 1932,01 & 49,61 & 4 & 100 & 300,4 \\
\hline & $* *)$ & 0,076 & 7,64 & 127,32 & 12,74 & 6 & 600 & 203,2 \\
\hline & $* * *)$ & 0,036 & 14,25 & 83,85 & 10,34 & 17 & 1700 & 411,9 \\
\hline & $\left.4^{*}\right)$ & 0,677 & 16,93 & 677,08 & 29,37 & 10 & 250 & 323,7 \\
\hline & $* *)$ & 0,024 & 2,41 & 240,84 & 17,52 & 1 & 100 & 56,5 \\
\hline & $* * *)$ & 0,009 & 3,75 & 41,61 & 7,28 & 9 & 900 & 124,3 \\
\hline & $5 *)$ & 0,451 & 11,27 & 901,46 & 33,89 & 5 & 125 & 203,7 \\
\hline & $* *)$ & 0,030 & 2,97 & 148,29 & 13,74 & 2 & 200 & 76,6 \\
\hline & $* * *)$ & 0,016 & 6,55 & 163,77 & 14,44 & 4 & 400 & 165,8 \\
\hline & $6 *)$ & 0,674 & 16,84 & 1122,80 & 37,82 & 6 & 150 & 291,5 \\
\hline & $* *)$ & 0,046 & 4,60 & 153,18 & 13,97 & 3 & 300 & 117,9 \\
\hline & $* * *)$ & 0,014 & 5,67 & 29,86 & 6,17 & 19 & 1900 & 201,0 \\
\hline & $7 *)$ & 0,854 & 21,36 & 610,32 & 27,88 & 14 & 350 & 417,0 \\
\hline & $* *)$ & 0,078 & 7,78 & 194,55 & 15,74 & 4 & 400 & 190,4 \\
\hline & $* * *)$ & 0,005 & 2,05 & 18,62 & 4,87 & 11 & 1100 & 79,6 \\
\hline & $8 *)$ & 0,624 & 15,61 & 520,20 & 25,74 & 12 & 300 & 314,4 \\
\hline & $* *)$ & 0,039 & 3,90 & 195,06 & 15,76 & 2 & 200 & 95,4 \\
\hline & $* * *)$ & 0,008 & 3,28 & 36,48 & 6,82 & 9 & 900 & 111,8 \\
\hline & $9 *)$ & 0,852 & 21,30 & 709,97 & 30,07 & 12 & 300 & 403,6 \\
\hline & $* *)$ & 0,113 & 11,33 & 161,84 & 14,36 & 7 & 700 & 287,5 \\
\hline & ***) & 0,027 & 10,93 & 182,22 & 15,24 & 6 & 600 & 271,0 \\
\hline & $10 *)$ & 0,652 & 16,30 & 592,73 & 27,48 & 11 & 275 & 320,1 \\
\hline & **) & 0,015 & 1,54 & 154,14 & 14,01 & 1 & 100 & 39,5 \\
\hline & $* * *)$ & 0,018 & 7,09 & 22,86 & 5,40 & 31 & 3100 & 264,6 \\
\hline \\
\hline \multicolumn{9}{|c|}{$\begin{array}{l}\text { Keterangan (Remarks): } \\
\text { lbds = luas bidang dasar (basal area) }\end{array}$} \\
\hline lbds/Ha & \multicolumn{8}{|c|}{$=$ luas bidang dasar per hektar (basal area per hectar) } \\
\hline$D_{l b d s}$ & \multicolumn{8}{|c|}{ = diameter pada rata-rata luas bidang dasar (diameter average basal area) } \\
\hline $\mathrm{N}$ & \multicolumn{8}{|c|}{$=$ Jumah pohon (number of trees) } \\
\hline $\mathrm{N} / \mathrm{Ha}$ & \multicolumn{8}{|c|}{$=$ jumlah pohon per hektar (number of trees per hectar) } \\
\hline SDI & \multicolumn{8}{|c|}{$=$ index kepadatan tegakan (stand density index) } \\
\hline$(*)$ & \multicolumn{8}{|c|}{$=$ Kelas pohon (trees level) } \\
\hline$(* *)$ & \multicolumn{8}{|c|}{$=$ Kelas tiang (poles level) } \\
\hline$(* * *)$ & \multicolumn{8}{|c|}{$=$ Kelas pancang (saplings level) } \\
\hline
\end{tabular}

